\title{
Reporting of Real Option Value Related to ESG: Including Complementary Systems for Disclosure Incentives
}

\author{
Nobuhito Ochi ${ }^{1}$ \\ ${ }^{1}$ Shobi University, Kawagoe, Saitama, Japan \\ Correspondence: Professor Nobuhito Ochi, Shobi University, Kawagoe, Saitama, Japan.
}

Received: June 6, 2018

Accepted: August 16, 2018

Online Published: Augus 21, 2018

doi:10.5430/ijfr.v9n4p19

URL: https://doi.org/10.5430/ijfr.v9n4p19

\begin{abstract}
This paper aims to consider ways of granting disclosure incentives in order for the Signaling Theory to develop and encompass the Legitimacy Theory. First, the author discusses that ESG strategies for managing stakeholder externalities create real option value that leads to corporate value creation, both as business opportunities as well as appeals to a company's legitimacy. At the same time as making real option thinking useful for strategic decision-making by management, it is necessary to structure non-financial information disclosure for convincing optionality related to controlling externalities from the viewpoint of investors.

Second, at the stage where conditions are not met for companies able to autonomously undertake management with a view to externalities, the author discusses how supplementing incentives for issuing signals regarding differentiation from other companies in the same industry relating to controlling externalities is required in the disclosure of non-financial information in statutory reporting systems. On the other hand, since the materiality of financial reporting is centered on risks and opportunities for business, disclosure regulations are required separately for material social values. Events not originally related to corporate value can create incentive for the fulfillment of accountability of companies by the mediation of "negative intangibles" through reputation.
\end{abstract}

Keywords: signaling, legitimacy, incentive compatibility, ESG disclosure, real option, comparability

\section{Preface}

Recently international initiatives have been activated for game change in the existing norms, aiming to control externalities such as the greenhouse effect. For example, in the 2015 SDGs (Sustainable Development Goals) by the United Nations (UN) and the Paris Agreement at COP21 (the UN Climate Change Conference) were set, in 2016 a process chart for agreement on detailed rules was made for the Agreement at COP22, and in 2017 the report (TCFD, 2017) to encourage disclosure of climate-related financial risks that affect financial stability by the FSB (Financial Stability Board) task force. The flow of international financial capital is sensitive to various risks, so as climate change and fossil fuels begin to be recognized in the business field as major risks, cases of divestment of capital related to fossil fuels as Stranded Assets by large institutional investors can be seen. Global companies who play important roles internationally understand climate change as a business chance, and actively take part in international rule-making, while ESG factors utilized in the long-range company value creation by even more private entities becomes main stream. Even President Trump's secession from Paris Agreement (in June, 2017) could not stop this global trend. (Note 1)

However, from the viewpoint of stockholders who require accountability by companies as receivers of information, it is true that the results of company activities on the basis of the capital invested by their stockholders should be attributed to them but social costs (externalities) of using natural capital without any cost cannot be said to be attributed to them, and so companies are required to account for how they use social or global public goods. But only stressing the concept of accountability or the inspiration of morality and ethics of company managers may result in leaving inefficiency in the control of externalities as is, so it is also important to deepen the thinking of driving forces to pragmatically encourage companies to disclose their social values. From the light of company risks in consideration of external forces mainly by NGOs and investors, the route for the Signaling Theory expanded to encompass the Legitimacy Theory (Accountability Theory) and to encourage companies to disclose more can be considered (Figure 1), but this will not necessarily lead to the disclosure of externalities with little relation to companies (e.g. outside their supply chains) (Ochi, 2015, p.256). 


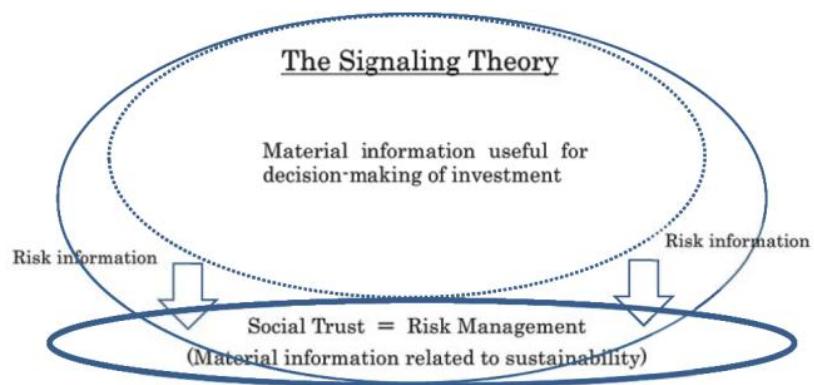

The Legitimacy Theory

Figure 1. Incentive compatibility of the signaling theory and the legitimacy theory

Source: Ochi, 2015, p.105

The purpose of this paper is to discuss how to give companies incentives by considering aspects of seeking business opportunities related to ESG as well as risk management, in order to widen the area in which the Signaling Theory and the Legitimacy Theory are balanced as incentive compatible in disclosure (hereinafter referred to as Incentive Compatible Balance), in order to overcome the problems mentioned. After first reviewing previous studies to take an overview of this paper's positioning among them, the author will discuss how the ESG strategy aimed to manage externalities of stakeholders as content to be disclosed by companies can explain their legitimacy and at the same time include real option value useful for company value creation. Second, while stressing comparability of information the author will discuss the requirements for disclosure mainly by these incentives, and also discuss how to supplement information asymmetry in disclosure by rules in order to make market discipline operate more efficiently for externalities control. Lastly, the author will summarize the paper and touch on future topics.

\section{Previous Studies and the Position of This Paper}

While information disclosure also is an effective policy measure in the field of application of internalization of environmental costs (external diseconomies) in environmental economics, it is conceivable that in disclosure theory based on mitigation of asymmetries of information, measures to improve discipline in disclosure toward control of externalities would be an important subject of consideration. An underlying cause of the inability to develop effective systems for internalizing externalities is the fact that factors such as natural capital are not subject to rights of ownership to begin with, and one key point concerns how to create a situation in which, absent allocation of rights of ownership, individual economic actors must address externalities as issues that concern them directly. Based on this understanding, this paper looks at the issue of how to draw out effective disclosure of information as a driving force behind corporate incentives to resolve externalities, and how effectively to assess such information externally.

Accordingly, consideration of asymmetrical information in environmental, social, and governance (ESG) areas has advanced from the perspectives of both usefulness of decision-making and pursuit of the policy objective of control of externalities. To widen the area of connection between the Signaling Theory and the Legitimacy Theory in corporate disclosure, this paper will analyze the structure of incentives toward control of externalities related to natural capital and other factors from the perspectives of information economics and contract theory. Then, it will discuss proposals for improving the situation through discipline in disclosure. Since under a contract theory approach information is treated as economic goods and how best to present information is considered while taking into account matters such as the issues raised by asymmetrical information and incomplete contracts, this can be considered a theoretical method capable of broad adaptation to resources such as natural capital that include nonmonetary benefits, instead of being applied solely to specific fields and phenomena.

Through now, acts intended to maximize surface-level profits depending on externalities have been encouraged, as a failure of the market arising from adverse selection. This has resulted from, for example, the inability to differentiate between a company that exploits natural capital and one that does not, due to the inability to discern the real price (cost). Accordingly, there is a need for theory and systems that would impact the actions chosen by economic actors (such as consumers and investors) through information differentiating companies from others, to incentivize disclosure of companies' efforts to lessen their dependence on externalities. Under contract theory, the process by which asymmetry of information is overcome by autonomous disclosure of information through competition among sellers is called "full disclosure." However, for such disclosure of information to function effectively, there is a need 
first of all to investigate the logic of incentivizing signaling through voluntary disclosure.

Prior studies concerning incentives for information disclosure that analyzed various issues arising from asymmetry of information included pioneering works by Akerlof (1970), Spence (1974), Stiglitz (1975), and Rothschild and Stiglitz (1976), among others, followed by theoretical research on autonomous disclosure of information (full disclosure), spearheaded by Milgrom (1981), Grossman (1981), and others. Milgrom (1981) argued that if sellers could conduct disclosure of reliable information at no cost, then sellers of products of higher-than-average quality would disclose quality information to the market, while buyers would look with doubt on the products of sellers who did not disclose information, so that increasing numbers of sellers would disclose information, leading to an equilibrium state at which all sellers disclosed information on product quality. Grossman (1981) also argued that if it were possible to prove, after the fact, the quality of products for which transactions already had been concluded then sellers would disclose all information about product quality.

Following these studies, theoretical studies were developed that attempted to understand the incentives for information disclosure by considering separately matters such as information production costs and maldistribution of management information, which were not addressed in Milgrom (1981) and Grossman (1981), in order to examine the conditions under which economic actors with information advantages would disclose information autonomously, with the goal of mitigating asymmetries of information in the market and the adverse selection that accompanies them. Next, Jovanovic (1982) and Verrecchia (1983) argued that even if there were costs to information disclosure, providers of high-quality products would have incentives to disclose information, but even so, in the event that information were not disclosed it would be difficult for market participants to determine if this failure to disclose were due to the presence of negative information (low quality) or to the fact that the positive information (high quality) was not worthy of disclosure to the extent that the possessors of the information were willing to pay the costs of its disclosure, and this too affected the act of information disclosure itself. Furthermore, as such theoretical studies accumulated, repeated empirical and experimental studies also were conducted to verify their theories.

In this context, this paper will attempt an approach to a framework of disclosure theory concerning externalities such as natural capital using contract theory as a frame of thought. Rather than an analytical study based mainly on mathematical models or an empirical and experimental study, it is a problem-solving study aiming to improve the current situation. (Note 2) Accordingly, it is oriented toward normative research offering considerations to contribute to solutions to current issues, through inductive thinking on observed facts (case studies of enterprises) aiming for an outside-in target hypothesis. While expressing the actions of decision makers in a mathematical model involves numerous simplifications and requires restrictive conditions that diverge from reality in order to confirm that there is a solution to the formularized problem, the point of this paper is not one of interpretation and analysis for observation of phenomena and strict proof of a proposition itself but one of proposing practical prescriptions to contribute to solving current problems (a method of incentivizing ESG disclosure), using the perspective of contract theory as a frame for thinking, and for this reason its discussion will be based on observation of case studies of actual enterprises.

Since the latter half of the previous century, in which real-world problems such as pollution could be seen to be worsening, theoretical and practical attempts toward corporate social accounting, intended to contribute to measurement and reporting of the environmental and other social impacts of corporate activities, have spread chiefly in Europe and North America. A large volume of research already has accumulated both domestically and internationally (examples include Estes (1976), Johnson (1979). Gray et al. (1987), and SIGMA (2003)). However, these were idealistic efforts, and since they attempted to systematize nonfinancial information in a manner resembling financial reports, using the concept of accountability to stakeholders as a methodological basis, they failed to spread when faced with the barrier of the difficulty of measuring such aspects. Rather than focusing on accounting measurement or quantification separate from management, this paper argues from the perspective that information on externalities can contribute to forward-looking risk management and securing of opportunities.

Put another way, it could be said that since corporate social accounting in the past lacked the perspective of designing incentives for economic actors, it failed to motivate people effectively to act in ways that would realize the financial and economic society considered desirable. This paper also considered the kinds of practical behavior that specific rules guide firms to take, reflecting the content of incentives on which actions are based, instead of simply sticking to the conceptual basis of accountability alone. In order to impact people's behavior to achieve the hoped-for objectives with regard to control of externalities such as natural capital, there is a need to understand in practical terms the behavioral patterns of individual economic actors and consider a system of balanced causes to draw out incentives toward such desirable behavior. 
In terms of the influence of ESG information on the usefulness of investment decisions, many empirical studies have been carried out in order to prove that ESG factors used for the valuation of a company have value relevance, and the effect of reducing capital costs has been demonstrated. However, the effect of value creation as an expectation of gaining opportunities for new cash flow is not necessarily clear. Under such circumstances, CSV (Creating Shared Value) by Porter and Kramer (2011) is one such way of thinking, and several cases are introduced in Kramer and Pfitzer (2016) as well. In this paper, the author conducts a theoretical reinforcement using the concept of real options on the path and causality of corporate value creation including such CSV cases, and this paper makes an original contribution by identifying the real option value of uncertain business opportunities oriented toward control of natural-capital externalities and clearly defining the disclosure rationale to visualize opportunities related to externality issues.

In the DCF method, discounting cash flow reflecting a high level of uncertainty in a high discount rate may lead to low asset value. However, if the manager can identify the option and take action flexibly, then the increase in uncertainty will mean a high valuation of the asset, so it is considered that real option thinking can provide a theoretical background that boosts corporate social and environmental approaches. In addition, by visualizing the real option value in corporate investment in the social and environmental fields through voluntary disclosure, positive evaluations can be obtained from investors, so it is considered to have a practical significance for deriving corporate management for externality control over SDGs etc. On the other hand, on the subject of disclosure regulations complementing the signaling of voluntary disclosure, this paper will lay the groundwork for the importance of adoption of disclosure standards enabling comparison among companies in the same industry from the theoretical perspectives of mitigating asymmetries of information for investors and the accompanying unraveling, in the direction of full disclosure, by disclosing parties.

\section{Voluntary Disclosure of the Real Option Value Related to ESG}

\subsection{ESG Strategies With the Real Option Thinking}

A route by which Signaling Theory would expand to encompass Legitimacy Theory and to encourage companies to disclose more can be considered from the perspective of company risk management in respect to external forces, mainly NGOs and investors. There is another route that differs from this viewpoint. For example, Kramer and Pfitzer (2016) recognized a market in which companies act as a kind of ecosystem and discussed the need to create "opportunities" by the collective impact that include all the components of that ecosystem. The concept of collective impact itself was previously advocated by Kania and Kramer (2011), and they listed the requirements for the creation of the collective impact as: i) a common agenda, ii) a share in valuation system, iii) mutual strengthening in activities, iv) continuous communication, v) an organization to support activities as a whole. Kania and Kramer (2011) discussed this as the collective impact among non-profit agencies, but Kramer and Pfitzer (2016) also targeted commercial companies, and widened the concept as a CSV with wider meaning useful for the solution of problems in externalities.

Kramer and Pfitzer (2016) introduced the good example of Yara International, a big company in the fertilizer field which could gain "opportunities" by analyzing the causes of "market failure" in Africa where the company attempted market development, and by broadly understanding the market as an ecosystem and including the Tanzanian government, international organizations, private enterprises, civic groups and others. Precisely, in order to overcome the circumstances (market failure) where poor farmers could not purchase fertilizer and even if they could purchase it they did not have enough knowledge on how to use it due to the political mistakes and corruption of the government and the lack of necessary roads, refrigerators to store vegetables, and an infrastructure for transportation. Yara International prepared a system for farm production and bays/roads/railroad, by cooperating with stakeholders (68 agencies including the government, NGOs, farmers, enterprises, etc.). In this way, the market was optimized by the realization of an infrastructure for farm production/distribution as well as taking into consideration the convenience of all the stakeholders. As a result the farmers grew autonomous, more fertilizer began to be sold and the ecosystem began to operate autonomously, and sales in Africa by Yara International grew by 50\%. Other good examples, such as Wal-Mart Stores, Inc., which tackled the problem of a lack of recycled plastic compounds by establishing a fund to support recycling projects all over the U.S. in collaboration with other companies, aiming to reduce Greenhouse Gas (GHG) emissions in its supply chain by 20 million tons and packaging costs.

Although it seemed to take some time, by attempting reform by including the business environment outside their value chains, sustainable businesses could be realized if the ecosystem around their business is optimized. In considering the efforts for companies to tackle externalities related to ESG, it tends to be stressful to think in the long run, but it is also important to think about broader areas. By taking into account not only the company's supply 
chains but also problems in externalities of its stakeholders outside the control of the company, it is necessary to acquire legitimacy and increase business opportunities. The author considers taking into consideration the real option value related to ESG to be useful for better understanding in the planning of a strategy, in order to find such "opportunities" in the problem of externalities as discussed below.

The conventional Discounted Cash Flow (DCF) method, even if the environment around company management changes, forecasts that cash flow in the future, on the basis that companies maintain the initial business strategies, and does not take into consideration the option of changing strategies corresponding to their uncertainties. Hence it cannot be adequately used in the valuation of strategic investments. Investment in a new business which does not directly result in profit but produces a source of profit in the future, has meaning equivalent to buying an option to participate in the business in earnest in the future, and is called a real option in the definition of an investment option to a real asset. This can be applied to other fields widely, including fields such as investment projects and R\&D, in order to analyze the flexibility of company management as a kind of option.

While it is true that values reflecting the possibilities and risks of a project can be derived under the DCF method as well, through scenario planning and setting of discount rates, these do not involve the assumption of intervention by proactive course changes by management in response to environmental changes, and when discounting cash flow over the long term, reflecting a high level of uncertainty in a high discount rate, they could lead to the conclusion that an investment should not be made because the resulting value is negative. Although the DCF method is valid under conditions of relative stability, since each matter addressed is independent in making a decision at the present time and does not reflect choices such as expansion, postponement, and withdrawal that differ from initial scenarios, there are limits to its validity under conditions that do not satisfy the preconditions for its application (Amram and Kulatilaka (1999)). This shows the significance of real options as a supplemental valuation method under conditions of uncertainty, and this option value should be recognized fundamentally on the corporate side. This could lead to boosting of activities in environmental and social fields related to reduction of corporate externalities.

It is important to identify options in strategic investment by a company first and to evaluate the option as a stance, not by focusing only on the mathematical aspects of the option theory, but by having new broader thinking (Amram and Kulatilaka (1999)). In the current analyzing method (DCF method), high uncertainty means low valuation of an asset. If the manager can identify the option and do something flexibly, increase in uncertainty will means high valuation of the asset, and the risk of losing such a risk (uncertainty) becomes even greater than actually taking the risk. While in the DCF method, the shift from low-carbon to decarbonation is recognized as an uncertainty not to be taken if possible as a business risk, when thinking of real options, such uncertainty is thought to be welcome and is recognized as an opportunity for the company. In an environment with uncertainty surrounding company management, the option value can be increased, but if the management cannot make a strategic decision, such value cannot be produced.

ESG investment by investors aims to improve investment performance in the mid- and long-term by taking into consideration non-financial ESG information as well as financial information in the valuation of a company. Many empirical studies have been carried out in order to prove that ESG factors used for the valuation of a company are relevant to market value and the investment performance. (Note 3) Two kinds of processes of company value creation in ESG can be recognized. One is the effect of reducing capital costs and the other is the effect of value creation as an expectation to gain opportunities for new cash flow. As for the former process, high level disclosure of information leads to improvement in the valuation of company management by investors and strengthens their conviction in the company's continued profit, and in turn, the reliability and robustness of the expected profit in the future, leading to the reduction in the estimation of risk and a decrease in the risk premium (for example, Dhaliwal et al. (2011), El Ghoul et al. (2011)).

On the other hand, regarding previous studies related to the latter process, many empirical studies in which the Real Option Theory is applied for investments for $\mathrm{R} \& \mathrm{D}, \mathrm{M} \& \mathrm{~A}$, venture companies, etc., or previous studies in which the Real Option Theory is applied in the context of the non-quantitative management theory can be seen. (Note 4) But the real option analysis focusing on the opportunities of company value creation by the management of externalities which a company confronts in fields related to the environment and society has yet to be developed. While continued cash flow and risk reduction are mainly considered in light of risk management of uncertainties on the basis of the DCF method in the (super) long-term in company value creation related to ESG, real option thinking of the creation of "opportunities" as a situation with optionality by responding flexibly to the change of a management environment with high uncertainty is useful in determining how the reduction of externalities by ESG-related company investment is related to its financial status. 


\subsection{Voluntary Disclosure of Real Option Values}

Recognition of real option values related to environmental and social fields fundamentally needs to be promoted on the corporate side, and by disclosing such value recognition through means such as integrated reports, the real option value can be recognized and used for ESG investment by investors. As a good example of disclosure aiming to express such "opportunities" is the strategy report by British American Tobacco, which promotes its strategic stance to play a role as a market leader in developing next-generation health-oriented products as well as focusing strategically on tackling the reduction of hazardous materials in order to create company value in the mid- and long-terms (British American Tobacco, 2016, pp. 2, 5, 20). And the Integrated Reports of DSM in the Netherlands (a global company in the fields of health, nutrition and materials) promotes non-financial factors related to sustainability as a growth driver and leads to its company value by relating this to SDGs (DSM, 2017, p.21). Other examples of disclosure using SWOT analysis are also available.

Real option thinking is important not only to create the appropriate decision-making by company management but also to satisfy accountability of those outside the company. So it is necessary to structure the non-financial information of a company in order to visualize the "opportunities" in a way that those outside the company can understand the situation with optionality in relation to the control of the externalities. (Note 5) As ESG information is useful only when it is used in the long-term forecast of earnings for the eyes of investors, it is important for them to be able to recognize the disclosed ESG information regarding how the company manages ESG risks and investment opportunities, and how it uses such information to improve company value. In the Natural Capital Protocol (NCC, 2016), regarding the relationship between the company and natural capital management, a viewpoint of dependence upon natural capital as well as the impact of externalities of a company are stressed, and some companies have already begun taking into consideration the factors in the Natural Capital Accounting and are focusing on environmental burden (negative externalities).

For example, companies such as Puma, KERING, Novo Nordisk A/S began trying to explain the monetary valuation of their ecosystem services upon which they and their value chains depend in their Environmental Profit and Loss Statements (EP\&L), before publication of the Natural Capital Protocol. It is not important how they measure environment burden but how they reduce it by understanding conditions of their supply chains, and prioritizing efforts to establish a stronger business process through the understanding of externalities and risks/opportunities and at the same time use such valuation in their communication with stakeholders such as investors, rating companies, NGOs, government agencies. In this way the Natural Capital Accounting captures and evaluates the effects and the dependence of company activities in connection with and on natural capital, and so the business risks and opportunities in relation to such natural capital are understood through factors that appeal to the company's legitimacy. At the same time, these can be problems to be tackled in the sustainable management and long-term company value creation. (Note 6)

The example of real option management to invest in "opportunities" with uncertainty in the future by TOYOTA among companies in Japan is truly remarkable and is published in the October 2015 "Toyota Environmental Challenge 2050", where the company visualized its target value to cut $\mathrm{CO}_{2}$ emissions by $90 \%$ in 2050 compared to 2010 levels as its " $\mathrm{CO}_{2}$ zero challenge." (Note 7) The Paris Agreement proposes a reduction in emissions to zero in several decades and whether companies accept or oppose the strict regulations on environment could change the automobile industry. In the meantime, a threat may cause a company to notice something and a big reform may create new business fields and provide a rare chance to dominate the market. Real option thinking may be very useful for Japanese companies which are reluctant to change except in rare cases, because they must promptly cope with these problems so as not to be left behind in the market. They should avoid being left behind and losing their market share.

According to Rappaport and Mauboussin (2001), company value (market capitalization) equals the value of the existing business of the company evaluated by DCF method added to its real option value. However, in the DCF method, the expected duration of expectation woven into the stock value of a company is calculated as the duration expected by the market during which the company continues to earn returns higher than the capital cost. So, in order to grasp how a higher than the average in the industry expectation can be woven into the stock value and how much of such expectation has the characteristics of a real option potentially, it is necessary to read the expectation only for existing business, assuming separately (subjective decision) that the expected period is for the existing business, not that the existing business is woven into the stock value. When the DCF value of the existing business is estimated by such a time-span, the amount of the market value of the stock subtracted by such value can be considered as the real option value woven into the stock value. (Note 8) The value of the existing business expected by this method 
included the expectation for growth in the future through the DCF method. It is considered that investors tend to highly evaluate PER companies, especially companies with characteristics of a venture company focusing more on the real option value of new opportunities despite themselves.

Euglena Co., Ltd., in Japan, is known to have succeeded in using euglena for food and can be listed as a typical case. While market capitalization of this company is already one of the highest among bio venture companies in Japan, this company is widening its business field and creating opportunities for growth while contributing to the reduction of externalities. (Note 9) The business strategy of this company is to distribute a stable cash flow gained from its healthcare business (functional food, cosmetics and medicines), based upon the availability of euglena as biomass in various fields, to "investments on the upper-side" (promising energy/environment business). In other words, according to the "business strategy" on its website, future business of this company has many opportunities for market creation not only in the successful field of biofuel, but also in the process for it. So if the company does not succeed in commercialization of the biofuel, it can expect to achieve "creation of new markets" and improvement in the gross profit rate in existing markets, and since petroleum-derived products such as oils and fuels are regulated from the viewpoint of emission rights, the company can achieve the commercialization of such biofuel earlier, before manufacturing costs grow to reach the market price depending upon the direction of regulations. This can only be called real option management aimed at the upside while managing downside risks in the middle of uncertainty (Fig. 2).

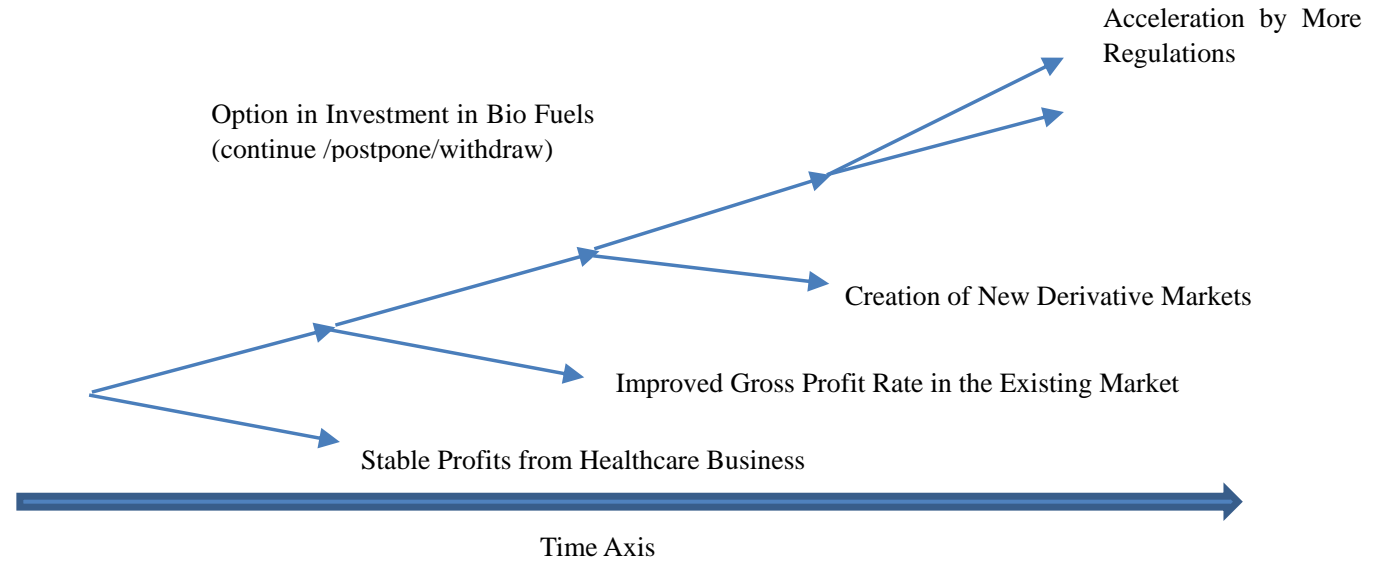

Figure 2. Uncertainty and option in the business strategy of Euglena Co., Ltd (Note 10)

Source: Ochi, 2018, p.40

As seen above, while investing, in stages, in development of biofuel using euglena the company reserves its options such as those of expansion, postponement, and withdrawal in response to environmental changes, while also reserving the growth option of developing future growth opportunities through projects related to biofuel investment. The option value of its euglena technologies also is recognized by investors through disclosure of business strategies. Backed by expectations of growth through such innovative solutions to environmental and social challenges, its price-earnings ratio (PER) also rose rapidly as its share prices increased after its IPO (listed on the Mothers board on December 20, 2012 and the First Section of the Tokyo Stock Exchange on December 3, 2014), and even in 2018, after investor enthusiasm had peaked, it still remained at a very high level of about 100 times. (Note 11) Amazon.com, mentioned in Footnote 8, was able to maintain high share prices even while recording massive losses, and the value of participation in a new market based on customer repeat usage rates was considered to be reflected as its option value, much higher than its corporate value as a simple online bookseller. The case of Euglena can be understood to involve a similar structure (Ochi, 2018, p.41).

\section{Complementary Systems for Incentives to Disclose a Signal}

\subsection{Complementary Systems for Extension of Incentive Compatible Balance}

One purpose of this paper is to give a theoretical explanation to "opportunities" which can lead to company value creation, and through it, encourage companies to publish Reports useful for the control of externalities. Therefore, the author expands the Incentive Compatible Balance between the Signaling Theory and the Legitimacy Theory and discusses the process in which companies seek for real option value including new business opportunities by the 
control of externalities, as an incentive for companies to disclose ESG information voluntarily. However, several conditions mentioned below must be met in order for companies to expand the concept of capital while taking into consideration externalities and to voluntarily disclose their practices into integrated thinking.

For example, for natural capital, there exists uncertainty related to externalities around a company. When the stock of natural capital is abundant, then the marginal value of such stock is stable midway through the change of the amount of such stock. But as the stock begins to decrease, its marginal value begins to increase, and when it increases beyond an economic/ecological threshold, regime shift will occur. The stock cannot recover automatically from the loss or the degradation any more (Pascual et al., 2010). Thus, companies are required to control the ecosystem in order to avoid such a regime shift for sustainability and as the existing ability to recover automatically (Resilience) decreases, uncertainty in the future becomes greater (Figure 3).

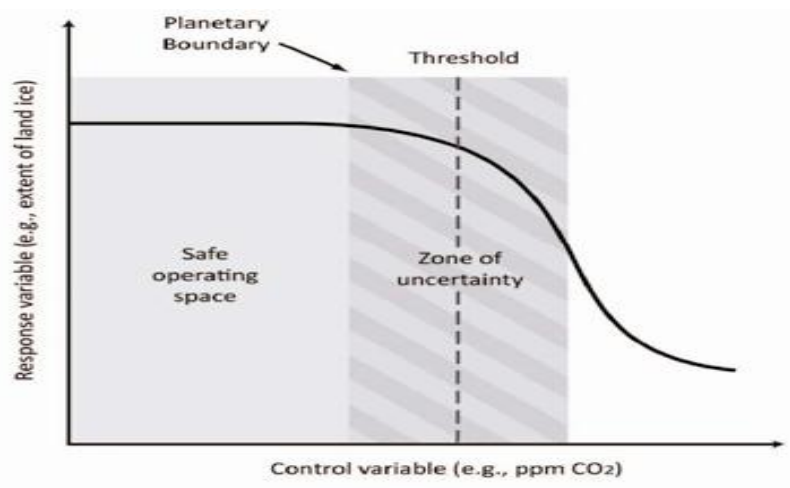

Figure 3. Planetary boundary and uncertainty

Source: Rockström et al. (2009) abstracted from Figure 2

Next, companies need to notice any existing uncertainty. It is not until they begin to notice it that the marginal utility of natural capital and other capitals, becomes higher and that the marginal value will change more sensitively even small changes in stock. That is, when natural capital is abundant enough for human activities, it is treated as natural or public goods, but as it begins to be noticed that such goods are decreasing and getting near to the limit, the necessity to control natural capital properly is proposed. Companies begin to be conscious of environmental change by themselves and not by any external pressure (change in normative consciousness) in noticing such a limit and the consciousness leads to recognition by companies of risks and opportunities, and gives rise to the incentive for them to respond to such.

Furthermore, in order to expand the Incentive Compatible Balance, market investors need to recognize the above-mentioned circumstances (Scott, 2006). It is broadly known that uncertainty increases and the effect of externalities becomes stronger, investors begin to focus more on information other than prices and financial status when deciding investment, and so investors begin to need the disclosure of non-financial information as a means to balance the market while taking into consideration such uncertainty. That is, it is important to complement the adjustment power of market using non-price/non-financial information as a signal and use it in the dealing process instead of price/financial information with inadequate adjustment power. This then leads to incentive for companies to disclose non-price/non-financial information to differentiate themselves.

Agreements in SDGs of the UN and Paris Agreements in 2015 and their follow-up afterwards, can be praised as playing an important role in decarbonation, as the change in normative consciousness in companies and investors. Strenuous effort to meet the conditions to encourage companies to make voluntary disclosure is required, but unless such changes in consciousness are deeply rooted in all the economic agents, the market will operate only depending upon nominal price/financial information despite efforts related to ESG, and as a result even incentive will be born for companies not making efforts for such improvement. In order to overcome this problem and to encourage companies to disclose non-financial information to compensate for the information asymmetry as to externalities, some heteronomous complementary remedies to prevent an economic agent from depending on externalities as a potential chance for profit are required. In order to realize this, it is necessary to complement the incentive for disclosing companies from another root through enforcement of such disclosure. 
The author has discussed how to provide incentive for companies to disclose more voluntarily. Another purpose of this paper is to consider remedies complementing the market system and the author regards incentive-making in the area of Product Liability as a successful example of system planning which encourages companies to tackle external problems, cope with related uncertainty and can complement market, as a policy means separate from discipline in disclosure. In other words, inadequacy of information and uncertainty regarding how much damage will be occur due to failure not taken into consideration when making agreement about a product and what consumer will suffer from, such damages cannot be identified, and so, due to the shift from liability with fault to liability without fault, a producer from making profits using the lack of information on the side of consumers is avoided while the damaged cannot foresee the risks related to the product, and at the same time incentive to encourage companies to make effort to prevent accidents through internalization of externalities in them is produced. It is rational in the light of laws and economics to impose such liability upon producers because most of the information for the proper response to such a situation is held only by the producers. The same thinking can be seen in the Extended Producers Responsibility (EPR), which encourages companies to develop and apply technology positively for environmental design such as waste prevention design through the strict rules of EPR.

The cost of safety in products and waste disposal should be paid by someone, and while risks are distributed among economic agents through regulations, the effect of such costs to the price is subject to rational decision in the market system. As for problems of externalities related to the Social Common Capital (Note 12) (Uzawa, 2000), companies as sellers can know the information in relation to the "real price (cost)" of their products including social costs related to externalities, while investors and buyers cannot. Between companies and stakeholders, there is overwhelming inequality in information about business, and companies have more information for the proper treatment of problems of externalities, and so it is the most effective to grant incentive for companies to improve conditions as in the case of Product Liability and Extended Producer Responsibility. It is necessary to make a disclosure system in which non-financial information can be used to evaluate qualitatively the "real price (cost)," can be a signal of the "health or pollution level" of profit for companies, and at the same time will give rise to the disclosure rule to prevent company activities from increasing externalities.

\subsection{System Design to Promote Signaling Behavior}

\subsubsection{Disclosure Regulations Within Statutory Financial Reporting}

Asian countries such as Taiwan, Hong Kong, Singapore and Malaysia have begun to require companies to disclose non-financial information such as ESG information by taking into consideration the EU directive (2014/95/EU), but if this movement to move forward only seeks to gain ESG money from investors, and lacks incentive-making for disclosure, such rules for disclosure will be ineffective for the policy purpose of the control of externalities.

In considering regulations for disclosure, the point is to create discipline in disclosure that can incentivize companies to compete in decreasing the "real price (cost)." Even if information on externalities can only be approximately and qualitatively understood, since companies can be motivated to obtain a good reputation by appealing (disclosing) to their consumers and others regarding how they can reduce such externalities as compared to other companies in the same industry, this would advance information disclosure through unraveling in the direction of full disclosure. On the other hand, while consumers cannot expect to gain direct benefit or profit from such information, they will not condone the destruction of natural capital, etc., with which they coexist and few will, in general, favor producers who achieve cost-down by exploitation, and will tend to give a lower evaluation to such producers. (Note 13) If information existing beforehand can be used to evaluate qualitatively the "health and pollution level of profit" can be shared, information asymmetry resulting in adverse selection may be diminished, and that the flow in which the incentive for companies to maximize the nominal profits depending such externalities can be stopped to a certain extent.

Such logic and process based upon the market mechanism is not necessarily new, and each kind of environmental label (such as ecological footprint, carbon footprint) can operate as a signal in comparison with other companies handling the same kind of product in the same industry. While these are still voluntary efforts mainly for each kind of product and cannot explain the overall management by a company in relation to the problems of sustainability including environmental burden, the author expects future development in the progressive efforts in the EU (Note 14) and other countries. When companies can evaluate carbon price by common criteria such as carbon pricing, such can be used for investors to make decisions in investment while considering future risks, and can give rise to a price signal effect that most conclusively matches GHG. However, while the carbon price can provide a source for investors and NGOs considering investment as to how a company regards the carbon price and can be used as a communication tool, a carbon tax mutually decided by each country imposing a $\mathrm{CO}_{2}$ emissions limit without borders 
will be expected to meet with practical difficulties, and the present price for emission rights, while not taking into account externalities, are difficult from one country to another for different reasons and so unification of these prices will still be a challenge.

When economic agents such as consumers and investors have inadequate information about the "real price (cost)," and despite they must make decisions under uncertainty, and use of the disclosure of non-financial information of the business is only as useful as the real price information. Given new information in relation to externalities, the balancing point in market can shift. For example, in the TCFD (2017) aimed at a new balancing of the market by encouraging companies to disclose the results of their risk assessment in relation to climate change. While such disclosure is done as a voluntary disclosure for the time being, disclosure as statutory financial report is expected in the future. It is designated for investors to evaluate companies based upon information equally and to make decisions regarding investment.

In the meantime, the Climate Disclosure Standards Board (CDSB) seeking the regulated disclosure of problems of externalities, after the IIRC (2013) and the widening recognition of risks accompanying the use of natural capital, expanded in 2013 to develop the framework for regulated disclosure of wider information on the environment and related information, as well as in relation to information on climate change. In June 2015, it published the CDSB Framework for Reporting Environmental Information \& Natural Capital and presented a framework for mainstream reporting of a broader range of information on the effects and dependence of and on natural capital, such as water resources and forests, use of various kinds of resources, land use, waste and spillage. (Note 15)

In addition, in October 2017, following exchange of opinions with the market s the Sustainability Accounting Standard Board (SASB) seeking the regulated disclosure of non-financial information in the U.S. published draft reporting standards for use in 79 industries (SASB, 2017) on the inclusion in financial reports under the SEC's jurisdiction of nonfinancial factors such as ESG. Suitable criteria for each industry related to ESG factors make it easier for investors to compare companies in the same field/industry, and it is very possible that the criteria can operate as a signal in comparison within the same field/industry. (Note 16) Whether SEC will adopt this or not is not known, but Bloomberg in the U.S. has already published the first "Impact Report" based upon SABS, in which the status of achievement of the aims was expressed quantitatively with a frank explanation of disclosure limitations. As disclosure according to the SASB standard becomes more popular among other companies in the same industry, there is greater possibility for investors to know clearly which company insufficiently discloses by comparison.

By comparing various recent initiatives in disclosure, we can see, as discussed in TCFD, that even when companies are required disclosure, without a common framework for disclosure of ESG-related risks, comparability will not be assured due to difficulty in deciding what is to be included in the disclosure. In addition a framework for disclosure that can enable a comparison with other companies in the same industry at least is necessary (TCFD, 2017, pp. 2, 18), and this thinking can be seen in each criterion for industries in SASB. On the other hand, for Integrated Reports and GRI, a method by discretion has been adopted in which companies can decide upon the materiality of ESG in their own process. Although companies can make disclosure in a way they decide, it may be difficult for investors to compare between companies. But those who promote this disclosure by discretion insist that standards with minimal index in each industry can enable investors to compare between companies, but disclosure of their originality (e.g. value creation strategy peculiar to each company) may be limited, and companies may disclose information which is required for disclosure.

Regarding this, from the viewpoint of this paper seeking a disclosure theory which would be useful not only for decision-making in investment but also for policy purposes such as control of environmental externalities, the main theme is to encourage investors to join by greater convenience in decision-making for problems of externalities and at the same time provide incentive to companies to disclose information related to such problems by making them aware of comparisons to other companies. Therefore, industry criteria are necessary as a framework for disclosure through market discipline for the control of externalities. Stressing comparability is expected to lead to mitigation of asymmetries in information among investors and, accordingly, to unraveling in the direction of full disclosure on the part of disclosing parties. If focused only upon the usefulness in decision-making, the approach by discretion and the approach with industry criteria are not necessarily considered to be exclusive, and a mixed approach as a common framework of disclosure may be practical, in which matters to be disclosed in order to compare with other companies are kept to a minimum and companies can, at discretion, add something signaling their own peculiarity. Also, when planning for system disclosure, it can be hoped that demonstrability (or verifiability) through means such as audit and assurance services would be secured as well.

Regarding cases where a signal related to an environmental problem also operates as an incentive in market dealing, 
LEED (Leadership in Energy \& Environment Design) run by the U.S. Green Building Council can be considered. LEED is a non-mandatory system in which a third party certifies the environmental performance of a building, and when the criteria set for each category related to sustainability (11 categories such as Materials \& Resources, Water Efficiency, Energy \& Atmosphere) are satisfied, a point is given. Certification categorized into four grades (Standard, Silver, Gold, Platinum) is given according to the total points. It is remarkable that real estate with high grade certification is handled on the market with a relatively high price and this leads to the incentive for real estate to be certified with a high grade (Bauer et al., 2011, p.36). This is a successful case which succeeds in signaling by branding.

Signaling by differentiation such as by LEED, and disclosure of broader information related to the environment etc., when visualized with a rating index that takes into account company management by a third party, can be used as in the infrastructure to support the reputation function by general users of information (stakeholders in the broader meaning). Valuation by comparison not only in the purchase market, but also in the labor or investment market, through the disclosure of non-financial information can motivate companies to create a good reputation for their company value. In addition to the many kinds of aforementioned environmental labels, progressive efforts such as evaluation indicators can be seen in the capital market also. (Note 17) These are expected, through comparable information, to play a role in providing positive incentive to companies not only to escape negative risks, but also as an opportunity to create their brand value.

\subsubsection{Disclosure Regulations From the Human Viewpoint}

It is expected that in each initiative leading to disclosure as a rule discussed beforehand, when disclosed in the way investors can compare the information on social values of a company with that of others in the same industry (if possible quantitatively), the incentive will encourage companies to respond to problems and thus the area in which market mechanism operates can include social values also. However, such disclosure is part of the financial report for investors and it is true that most of them encourage companies to disclose more about social values useful for other stakeholders, but from the human viewpoint they cannot sufficiently cover the well-being of people and maintenance of Social Common Capital. For example some social values which have little to do with business still might not be given attention.

The points of contact with social value on the corporate value chain are stratified into the layers of (i) generic social issues that may be important to society but do not influence the company's long-term competitiveness, (ii) social issues that are affected significantly by the company's activities in the ordinary course of business, and (iii) social issues that are factors in the external environment and significantly affect the drivers of competitiveness in the countries where the company does business. A company's activities need to be centered on the second and third of these domains (Porter and Kramer (2006), pp. 83-84). For this reason, there are concerns that in the first of these domains, matters such as $\mathrm{CO} 2$ emissions outside the domain of management of company activities (Scope 3, including indirect emissions), human-right issues, and preservation of endangered species might be subject to disclosure of information only as it suits the company. When the results of stakeholder management are not reflected in shareholder value, disclosure of ESG information, which concerns the sustainability not of the company but of society as a whole, is important not to investors (shareholders) but from a multi-stakeholder approach, and there is a strong tendency for a gap to form between shareholder value and the value demanded by society.

In other words, thinking regarding materiality in financial reports pays attention to the risks which may harm people in the light of risks and opportunities in business, and so from the human viewpoint, materiality for people which has little to do with business should be considered separately. While the vertical axis of the Materiality Matrix of GRI (index that affects materially the valuation and decision-making by stakeholders) is adopted by many companies, the horizontal axis (index reflecting remarkable effects (impacts) of reporting companies on the economy, environment and society) tends to be substituted by impacts on the reporting companies (materiality in the light of risks and opportunities in business) in the financial report for investors. For example, in Integrated Reports, a matter is material "if it could substantively affect the organization's ability to create value in the short, medium and long terms," while in SASB, materiality is defined as "the substantial likelihood that disclosure of the omission may be viewed by a reasonable investor as having significantly altered the "total mix' of information made available."

On the other hand, among material social values other than problems such as climate change for which normative consciousness is being formed globally, there many values which differ by people or organizations with different cultures and creeds, interests and experiences, or which can change over (Ochi, 2015, p. 66). Thus it may be difficult to require the formation of a normative consciousness which can sufficiently conform to the direct regulations, but now that some material social values are being brewed as issues to be evaluated separately by voting behavior in 
consumption and investment (soft laws), it may be necessary to establish a norm for disclosure by hard laws which require companies to disclose how they use Social Common Capital, and to share such information with society.

For example, in the Modern Slavery Act in May 2015, companies are required to declare (report) what steps they take in order to assure that slavery and slave trade do not exist in throughout their supply chains businesses from April 2016. When a company does not declare such, the Secretary of State for Home Affairs may seek an injunction of the company from the Supreme Court. If the company still does not comply, a fine is imposed. The reports are not examined by the British Government, but rather by NGOs, universities and other civil organizations who are expected to monitor the behavior of companies. Major risks which affect the activities of people and their relationship in business, not the risks of companies, are focused on.

While disclosure regulations make transparent to the public what kinds of actions are taken by companies and what kinds of actions are not, and can thus provide enough information for investors, customers, and the public to decide whether or not to deal with a company. Declaration that an organization did not take any action would not only harm their reputation in business, but also expose it to criticism from consumers or NGOs. In France as well, an act was established in February 2017, requiring companies larger than certain scale to do due diligence regarding human rights. This applied not only to companies but also their affiliates and suppliers, to disclose the results as a framework to improve the transparency as to company activities using disclosure regulations. A provision for conflict minerals disclosure was made by Dodd-Frank Wall Street Reform and the Consumer Protection Act in the U.S. and requires public manufacturing and selling companies to investigate and disclose whether or not their deals in certain minerals provide financial support to conflicts, in order to shut down money sources of warlords in and around the Democratic Republic of the Congo.

It is necessary to require companies to disclose by themselves non-financial information for examination of an act and omission by a company in comparison with others in relation to matters which require a person to choose among norms, in order that the disclosure incentive through company reputation operates effectively. The problem of externalities is rooted in that none can claim ownership to any Social Common Capital such as natural capital, but a bad reputation by the improper use of Social Common Capital, which is a kind of public goods, has the same effect as negative ownership (Note 18) in the form of "negative intangibles" (Ochi, 2015, p.145). In other words, while a company does not have the right to control natural capital, the reputation that they neglected to control it properly when they could, will damage their company value as "negative intangibles." As a result, (although they have no ownership) they are more anxious to use it effectively (in the way of controlling externalities), and have incentive to face their accountability as a chance to disclose that they have no negative ownership.

\section{Conclusion}

In this paper, the author explains the ESG strategy for managing externalities of stakeholders enables companies to promote business legitimacy and at the same time can include real option value useful for company value creation, in order to widen the area in which the Signaling Theory and the Legitimacy Theory can be balanced as incentive compatible with disclosure. Real option thinking can be applied as a strategy to find business opportunities in relation to the control of externalities, and private bodies such as business leaders and institutional investors all over the world support the governments at COP21. It is important to analyze ESG factors in the light of real option, as it will legitimize decision-making by company managers as well as accountability for those outside. While it is necessary to structure the disclosure of non-financial information with the aim of visualization of "opportunities" in order that real option value in relation to the control of externalities can be understood from outside, it will be important also for academic researchers to gather case study evidence using this thinking with a quantitative option value calculation in mind.

Next the author discussed conditions and limitations in the promotion of voluntary disclosure by incentive, and further discussed the way to regulate disclosure for the control of externalities in stages where conditions have not yet been arranged for voluntary disclosure of integrated management with externalities in mind. ESG information related to a company is varied to such a degree much that, if more companies disclose such information with little materiality for decision-making, it would be difficult for information receivers to evaluate them. Especially from the point of view of environment policy, it is necessary to make a system where stakeholders can compare and evaluate the response to requirements for non-financial information of each company with that of other companies in the same industry, by officially announcing the criteria of disclosure of non-financial information to enable comparison between companies in the same industry. While it is inevitable that financial reports focus on risks and opportunities in business, and other regulations for disclosure may be required to correspond to the degree of risk of harm to people, events not originally related to corporate value of companies will become matters of financial interest for 
them by affecting reputation, and can provide incentives for management of companies to cope with such events. "Negative intangibles" operate as negative ownership, and can be an incentive to fulfill accountability of company.

Under conditions in which Social Common Capital cannot be assigned ownership, even if the ultimate goal in addressing the issue of global warming is a market-based solution through carbon pricing, reputation, by comparison with other companies, plays a practical and important role in the stages before attainment of this ultimate goal. Comparable information is necessary for this purpose, and while comparability of information can be identified in the forms of both time-series comparison of information within a single firm (vertical comparability) and comparability between companies and between industries (horizontal comparability), it is through securing horizontal comparability that reputation can be achieved through comparison of essential quality with other companies. In doing so, in order to generate comparable information that could impact the selection behavior of economic actors (e.g., consumers and investors), there is a need to design incentives by which the parties causing externality issues disclose on their own information concerning their efforts toward reduced dependence on externalities, because individual enterprises themselves are the parties that know their own business.

Improving comparability between companies in the same industry would not necessarily conflict with faithful representation of information, and particularly with regard to nonfinancial information such as ESG, the central focus of this paper, it is thought that the contemporary role of such information in contributing to investor decision-making in the capital markets should be reassessed proactively. While there are differences between financial and nonfinancial information, comparability of accounting information (i.e., financial statements and the notes thereto) has long been a subject of debate, and there is room for future study, both theoretical and empirical, of related matters including the distinctions between financial and nonfinancial information and whether they vary by purpose of disclosure. At the same time, in pursuing the process and rationale of measures to bridge the gaps between current conditions and the ideal state (i.e., control of externalities) from the perspective of considering prescriptions to contribute to solving real-world problems, this paper has contributed to normative consideration of system design through reference to essential ways of thinking from contract theory. Still, the possibilities for use of disclosure cost-benefit analysis using mathematical models based on contract theory, and of experimental or other approaches, remain topics for future consideration.

\section{References}

Akerlof, G. (1970). The Market for Lemons: Quality Uncertainty and the Market Mechanism. Quarterly Journal of Economics, 84(3), 488-500. https://doi.org/10.2307/1879431

Albuquerque, R., Durnev, A., \& Koskinen, Y. (2014). Corporate Social Responsibility and Firm Risk: Theory and. Empirical Evidence. Discussion Paper No.9533, Center for Economic Policy Recearch.

Amram, M., \& Kulatilaka, N. (1999). Real Option: Managing Strategic Investment in an Uncertain World. Harvard Business School Press, Boston.

Asaoka, D. (2012). Kigyo seicho to Seido shinka - Senzen Denryoku Sangyo no Keisei (The Growth of Companies and the Development of Systems, the Formation of Power Generation Industry). NTT Publishing Co., Ltd, Tokyo.

Bauer, R., Eichholtz, P., \& Quigley, J. (2011). How Green is Your Property Portfolio?: The Global Real Estate Sustainability Benchmark. Rotman International Journal of Pension Management, 4(1), 34-43.

Besley, T., \& Ghatak, M. (2007). Retailing Public Goods: The Economics of Corporate Social Responsibility. Journal of Public Economics, 91(9), 1645-1663. https://doi.org/10.1016/j.jpubeco.2007.07.006

British American Tobacco. (2016). Annual Report, Strategic Report 2015. British American Tobacco, London.

Clark, G., Eeiner, A., \& Viehs, M. (2015). From the Stockholder to the Stakeholder: How Sustainability Can Drive Financial Outperformance. Retrieved February 28, 2018, from http://arabesque.com/research/From_the_stockholder_to_the_stakeholder_web.pdf

Dasgupta, P. (2001). Human Well-Being and the Natural Environment. Oxford University Press, Oxford. https://doi.org/10.1093/0199247889.001.0001

Dhaliwal, D., Li, O., Tsang, A., \& Yang, Y. (2011). Voluntary Nonfinancial Disclosure and the Cost of Equity Capital: The Initiation of Corporate Social Responsibility Reporting. Accounting Review, 86(1), 59-100. https://doi.org/10.2308/accr.00000005

Dixit, A., \& Pindyck, R. (1995). The Options Approach to Capital Investment. Harvard Business Review, 73(3), 
105-115.

DSM. (2017). Integrated Annual Report 2016. DSM, Heerlen.

El Ghoul, S., Guedhami, O., Kwok, C., \& Mishra, D. (2011). Does Corporate Social Responsibility Affect the Cost of Capital?. Journal of Banking \& Finance, 35(9), 2388-2406. https://doi.org/10.1016/j.jbankfin.2011.02.007

Ernst \& Young ShinNihon LLC. (2016, November). Zizoku Kanou na Kaihatu Mokuhyo (SDGs), Senshin Kigyo no Torikumi (The Sustainable Development Goals (SDGs, the Efforts by Progressive Companies). CCaSS News Letter, Tokyo.

Estes, R. (1976). Corporate social accounting. John Wiley \& Sons, New York, NY.

Ferreira, N., Kar, J., \& Trigeorgis, L. (2009). Option Games The Key to Competing in Capital-Intensive Industries. Harvard Business Review, 87(3), 101-107.

Gray, R., Owen, D., \& Maunders, K. (1987). Corporate Social Reporting: Accounting and accountability. Prentice Hall, London.

Grossman, S. (1981). The Informational Role of Warranties and Private Disclosure about Product Quality. Journal of Law and Economics, 24(3), 461-483. https://doi.org/10.1086/466995

Institute for Global Environmental Strategies (IGES). (2017). Beikoku no Pari Kyotei Ridatu Hyomei ni Kansuru IGES comment - Sekai no Datu tanso ka ha Tomaranai (The IGES Comment for the declaration of U.S. leaving the Paris Agreement - Decarbonation in the world cannot be stopped). Retrieved February 28, 2018, from http://www.iges.or.jp/files/announcement/20170602/iges_20170602.pdf

International Integrated Reporting Council (IIRC). (2013). The International $\langle I R\rangle$ Framework. IIRC, London.

Iriyama, A. (2015, August). Real Option Riron (The Real Option Theory). Diamond Harvard Business Review, 124-135.

Japan Association of Real Options and Strategy (Ed.). (2006). Real Option to Keiei Senryaku (Real Option and Management Strategy). Sigma Base Capital Corp, Tokyo.

Johnson, H. (1979). Disclosure of corporate social performance. Praeger, New York, NY.

Jovanovic, B. (1982). Truthful Disclosure of Information. The Bell Journal of Economics, 13(1), 36-44. https://doi.org/10.2307/3003428

Kania, J., \& Kramer, M. (2011). Collective Impact. Stanford Social Innovation Review, Winter, 35-41.

Kawaguchi, Y. (2004). Real Option no Shiko to Gizyutu (The Thinking and Technology of Real Option). Diamond Inc, Tokyo.

Kramer, M., \& Pfitzer, M. (2016). The Ecosystem of Shared Value. Harvard Business Review, 94(10), 80-89.

Milgrom, P. (1981). Good News and Bad News: Representation Theorems and Applications. Bell Journal of Economics, 12(2), 380-391. https://doi.org/10.2307/3003562

Natural Capital Coalition (NCC). (2016). Natural Capital Protocol. NCC, London.

Nielsen. (2015). The Sutainability Imperative: New Insights on Consumer Expectations. Nielsen, New York, NY.

Ochi, N. (2015). Zizoku Kanosei to Innovation no Togo Hokoku - Hi zaimu Zyoho kaizi no Dynamics to Shinrai sei (The Integrated Reporting of Sustainability and Innovation, the Dynamics and Reliability of the Disclosure of non-Financial Information). Nippon Hyoronsha Co., Ltd, Tokyo.

Ochi, N. (2018). ESG Kaizi no Incentive Fuyo wo Meguru Kosatsu -Shizyou Mechanism wo Hokan suru Siten kara (Consideration of granting incentives of ESG Disclosure: From the Viewpoint of Complementing the Market Mechanism). Sangyou Keiri, 78(2), 35-46.

Pascual, U., et al. (2010). The Economics of Valuing Ecosystem Services and Biodiversity (Chapter 5). In Kumar, P. (Ed.), The Economics of Ecosystem and Biodiversity: Ecological and Economic Foundations (pp. 1-133), Earthscan, London.

Porter, M., \& Kramer, M. (2006, December). Strategy and Society: The Link between Competitive Advantage and Corporate Social Responsibility. Harvard Business Review, 78-94.

Porter, M., \& Kramer, M. (2011, January-February). Creating Shared Value. Harvard Business Review, 62-77.

Rappaport, A., \& Mauboussin, M. (2001). Expectation Investing. Harvard Business School Press, Boston. 
Rockström, S. W., et al. (2009). Planetary Boundaries: Exploring the Safe Operating Space for Humanity. Ecology and Society, 14(2). https://doi.org/10.5751/ES-03180-140232

Rothschild, M., \& Stiglitz, J. (1976). Equilibrium in Competitive Insurance Markets: An Essay on the Economics of Imperfect. Information. Quarterly Journal of Economics, 90(4), 629-649. https://doi.org/10.2307/1885326

Scott, W. (2006). Financial accounting theory (4th ed.). Prentice Hall, Toronto.

SIGMA. (2003). The SIGMA Guidelines: Putting Sustainable Development into Practice. SIGMA, London.

Spence, M. (1973). Job Market Signaling. Quarterly Journal of Economics, 87(3), 355-374. https://doi.org/10.2307/1882010

Stiglitz, J. (1975). The Theory of 'Screening', Education, and the Distribution of Income. American Economic Review, 65(3), 283-300.

Sustainability Accounting Standards Board (SASB). (2017). Exposure Draft, Proposed Changes to Provisional Standards. SASB, San Francisco.

Task Force on Climate-related Financial Disclosures (TCFD). (2017). Final Report, Recommendations of the Task Force on Climate-related Financial Disclosures. TCFD, New York, NY.

United Nations Environment Programme Finance Initiative (UNEP FI)., \& Mercer. (2007). Demystifying Responsible Investment Performance: A Review of Key Academic and Broker Research on ESG Factors. UNEP FI, Geneva, and Mercer, New York, NY.

Unruh, G., Kiron, D., Kruschwitz, N., Reeves, M., Rubel, H., \& Felde, A. (2016). Investing for a Sustainable Future Investors. MIT Sloan Management Review, Spring, 1-29.

Uzawa, H. (2000). Shakai teki Kyoutuu Shihon (Social Common Capital). Iwanami Shoten, Tokyo.

Verrecchia, R. (1983). Discretionary disclosure. Journal of Accounting and Economics, 5(1), 179-194.

\section{Notes}

Note 1. $\mathrm{CO} 2$ emissions by U.S. companies tackling the problems and those signing the Paris Agreement to express continuation of their efforts including individual States of the U.S. still accounts for almost for $90 \%$ of the emissions all over the world (IGES, 2017, p.1).

Note 2. The subjects of consideration in this paper are centered on disclosure of nonfinancial information, not only covering autonomous disclosure but also retroactive to the issues of incentives in design of disclosure regulations.

Note 3. According to the survey summarizing research on the effects of ESG investments, most show the positive effect of ESG (UNEP FI and Mercer, 2007, pp. 13-14, 39; Clark et al., 2015, p. 9).

Note 4. For example, Dixit and Pindyck (1995), Amram and Kulatilaka (1999), Yamaguchi (2002), Kawaguchi (2004), Japan Association of Real Options and Strategy (2006), Ferreira et al. (2009), Iriyama (2015) can be listed.

Note 5. It is necessary for companies to note uncertainty related to the future business environment and the risks and opportunities to be born there, and to show clearly their long-term and strategic consideration of the option value. For example, the ITO EN Integrated Report 2016 in Japan, though not using the term of real option, promoted that the company had carried out full amount purchase from its farmers, reused abandoned farms, and used a recycle system for used tea leaves, etc., in order to improve its long-term and strategic company value.

Note 6. In order to support the efforts by companies aiming to realize the SDG of the U.N. including the preservation of natural capital, the SDG Compass was designed, and in addition to this, the United Nations Global Compact, in collaboration with KPMG, created the SDG Industry Matrix to introduce examples of business opportunities, and has built a website (Global Opportunity Explorer) to introduce examples of business opportunities in collaboration with Sustania (Denmark) and DNV GL (Norway). The BSDC (Business and Sustainable Development Committee) has published a research paper (Better Business, Better World) showing the 60 business opportunities (Hot Spots) in relation to its goals. In the meantime, more and more global companies have been named as main player, private companies in SDGs in foreign countries, seeking to use this trend for sustainable business strategies and the creation of new business opportunities. Anheuser-Busch InBev, Unilever, Novo Nordisk A/S, Anglo American PLC and other companies have made positive disclosure of information related to SDGs (Ernst \& Young ShinNihon LLC, 2016).

Note 7. In fact, the announcement of the company plan on October 14, 2015 was highly evaluated on the stock 
market. For example SMBC Nikko Securities Inc., evaluated this as, "we want to highly evaluate the difficult challenge to lead efforts as a world leading company to achieve co-existence and co-prosperity with the global environment," resulting in an increase in the stock price of the company. SONY Corp., Ricoh Japan Co., Ltd., Fujitsu Ltd. and others also announced a zero challenge in $\mathrm{CO} 2$ emissions and gained attention inside and outside Japan.

Note 8. Rappaport and Mauboussin (2001) estimated that $\$ 35$ of Amazon.com stock valued at $\$ 64$ (February 22nd, 2000 ) was the value of the existing business and the other $\$ 29$ was the real option value woven into the market. The company's innovativeness in various fields in the meantime can be imagined. Its stock price as of the end of 2017 rose to $\$ 1,169$.

Note 9. The founder of this company saw the problem of hunger by malnutrition during his travel in Bangladesh when he was a university student, and in order to help solve the nutrition problem, he founded the company in August 2005, as a bioventure company aimed at solving food problems all over the world by euglena (microalgae) with its abundant nutritional value. In December of the same year, the company succeeded for the first time in the world in the mass cultivation of euglena outdoors, and later promoted the functional food business using euglena and the $R \& D$ aimed at commercialization of the production of biofuels derived from euglena and the improvement of the global environment problems (extracted from the company Website).

Note 10. Regarding actions in response to conditions whose meaning, as time flows, will be known more precisely, if for example, certain parameters (such as volatility, or option term) were assumed audaciously, it would not be impossible to show the value of growth option in quantity. However, rigorous methodologies including those that show issues related to environment/society have not yet been established. Such an audacious assumption would lead to the risk of only a false impression of numbers spreading like wildfire. Academic research should collect examples where real option is used as a way of thinking to make qualitative decisions first.

Note 11. International comparison shows that PER tends to converge within a certain range, averaging around 15 times.

Note 12. Dasgupta (2001) proposes the Capital Approach, which recognizes the maintenance of various capitals existing in society among generations as the requirement for sustainable development and contains the extension of production factors in the production base. In the Capital Approach, the focus is shifted from consumption to capital, the Social Common Capital (Uzawa, 2000) is targeted as well as private economic goods.

Note 13. According to the research of consumer consciousness, there are several findings that companies' CSR activities will play an important role in consumer purchasing motivation (Niclsen, 2015; Albuquerque et al., 2014; Besley and Ghatak, 2007).

Note 14. The European Commission finished in 2013 the development of the evaluation indicators of environmental footprint and its method, taking into consideration the results of the pilot businesses using this is now tackling with the designation of the rules for each field/industry and considering this in policy.

Note 15. GRI founded the Global Sustainability Standards Board (GSSB) as its independent board in 2015, and shifted from G4 Guidelines to the GRI Standard, in which the requirements for reporting are clarified, the module structure is adopted to enable flexible updating of reports, and the author feels that the convenience to be used for coming regulated disclosure is considered.

Note 16. It is important to evaluate the management of a company compared to that of other companies as well as the number of externalities, and so the comparison among different companies in different industries with different forms of environmental burden and convenience (e.g. airplanes and consumer electronics) might be ineffective.

Note 17. As rating information for ESG investors, financial information vendors such as Dow Jones \& Company, Inc., Bloomberg L.P., and Thomson Reuters and sustainability investment rating/research companies such as Robeco SAM, Trucost and Sustainalytics have already begun. Such information, with targets and methods of evaluation becoming more clearly understood, whose presence in the capital market is further enhanced, is expected to become an indicator for a broader and broader range of stakeholders.

Note 18. According to Asaoka (2012) pp.189-190, carbon taxes and the dealing of emission rights operates as negative ownership to clarify whom materials with externalities (e.g. CO2) belong to institutionally. But as already explained, even now carbon pricing remains to be the task to be done in the future, the regulation through disclosure of non-financial information enabling to estimate externalities, and then reputation for disclosing companies can be expected to play an important role in companies disclosing whom negative ownership belong. 